\title{
Mitotic Studies on Combretum Loefl. from Nigeria
}

\author{
Chimezie Ekeke, Ikechukwu O. Agbagwa*, Bosa E. Okoli
}

Department of Plant Science and Biotechnology, University of Port Harcourt, Port Harcourt, Nigeria.

Email: *ikechukwu.agbagwa@gmail.com, *ikechukwu.agbagwa@uniport.edu.ng

Received January $10^{\text {th }}, 2013$; revised February $14^{\text {th }}, 2013$; accepted February $24^{\text {th }}, 2013$

\begin{abstract}
Cytological studies involving root-tip chromosomes of ten Combretum species belonging to the family Combretaceae from Nigeria were carried out. The result showed that C. platypterum, C. racemosum, C. constrictum, C. bracteatum and a yet to be identified Combretum sp.2 have a chromosome number of $2 \mathrm{n}=26$. Also, C. racemosum, C. zenkeri and Combretum sp.3 (yet to be identified) have a chromosome number of $2 \mathrm{n}=39$. A basic chromosome number of $\mathrm{x}=13$ for the genus is therefore proposed.
\end{abstract}

Keywords: Combretum; Combretaceae; Cytology; Mitotic Chromosomes

\section{Introduction}

Combretaceae is family of plants with 20 genera and 600 species of tropical and subtropical regions of the world [1]. In West Africa, the family Combretaceae is represented by 9 genera with 72 species and the genus Combretum Loefl. is the largest genus with 48 species and 8 imperfectly known species [2]. In Nigeria, the genus Combretum Loefl. is represented by 25 species which are mainly straggling shrubs or lianes [3]. The acid extracts from the mature leaves of $C$. bracteosum are used as mild steel corrosion inhibitor [4] while some other members of the genus produce gum exudates of high viscosity and high molecular weight, usable in bio-engineering $[5,6]$. Numerous ethnopharmacological, anti-oxidant and antimicrobial characteristics have been reported for members of the genus [7-10]. Despite the importance of members of this genus, there is paucity of cytotaxonomic information regarding the species.

The chromosome number as one of the three headings of cytotaxonomy is of great importance in taxonomic studies. Stace [11] stated that "chromosome number and homology largely determines pairing behaviour at mitosis, which in part govern the level of fertility of hybrids and hence the breeding behaviour and pattern of variation of populations". Apart from reports of basic number of $\mathrm{x}=12$ and 13 [12] for the family, there is no known report on the chromosome numbers of members of this genus in Nigeria. From the work of Stace [11], it is obvious that knowledge of the chromosome number is important in the manipulation and improvement of plant

*Corresponding author. species. This and the need to improve on the taxonomy of the genus underscore this study on a genus with great horticultural importance. The findings of this study represent the first known report of chromosome numbers of Combretum species in Nigeria.

\section{Materials and Methods}

Plant specimens were collected from various parts of SouthSouth and South-Eastern Nigeria as shown in Table 1. These specimens were taken to Forestry Herbarium Ibadan (FHI) and properly identified by comparing with deposited materials in the herbarium and reference to the Flora of West Tropical Africa [2].

Cytological examinations were carried out on root tips generated from the specimens collected between 8 a.m. and 10 a.m. The young root tips were pretreated with $0.02 \mathrm{M}$ 8-hydroxyquinoline for 3 to $4 \mathrm{hr}$, fixed in Carnoy's fluid (glacial acetic acid and ethanol, 1:3 ratio), transferred to $70 \%$ ethanol and stored in a refrigerator till required. Thereafter, the specimens were removed, placed in $18 \%$ hydrochloric acid ( $\mathrm{HCl}$ ) for 2 minutes, squashed using 2\% FLP Orcein, viewed under a Meiji microscope (MX 4200L) and chromosome number determined [13]. Measurement of chromosome lengths was achieved with an ocular (X10) fitted with a micrometer rule and good chromosome plates photographed with Canon A480 digital camera fitted on Leitz Diaplan microscope. For each species, ten chromosomes were randomly measured from five different preparations. The lengths of the chromosomes were summed up for each species; the mean lengths and standard deviations thereof were statistically computed in EXCEL. 
Table 1. Species name, locality, co-ordinates and dates of collection of Combretum species studied.

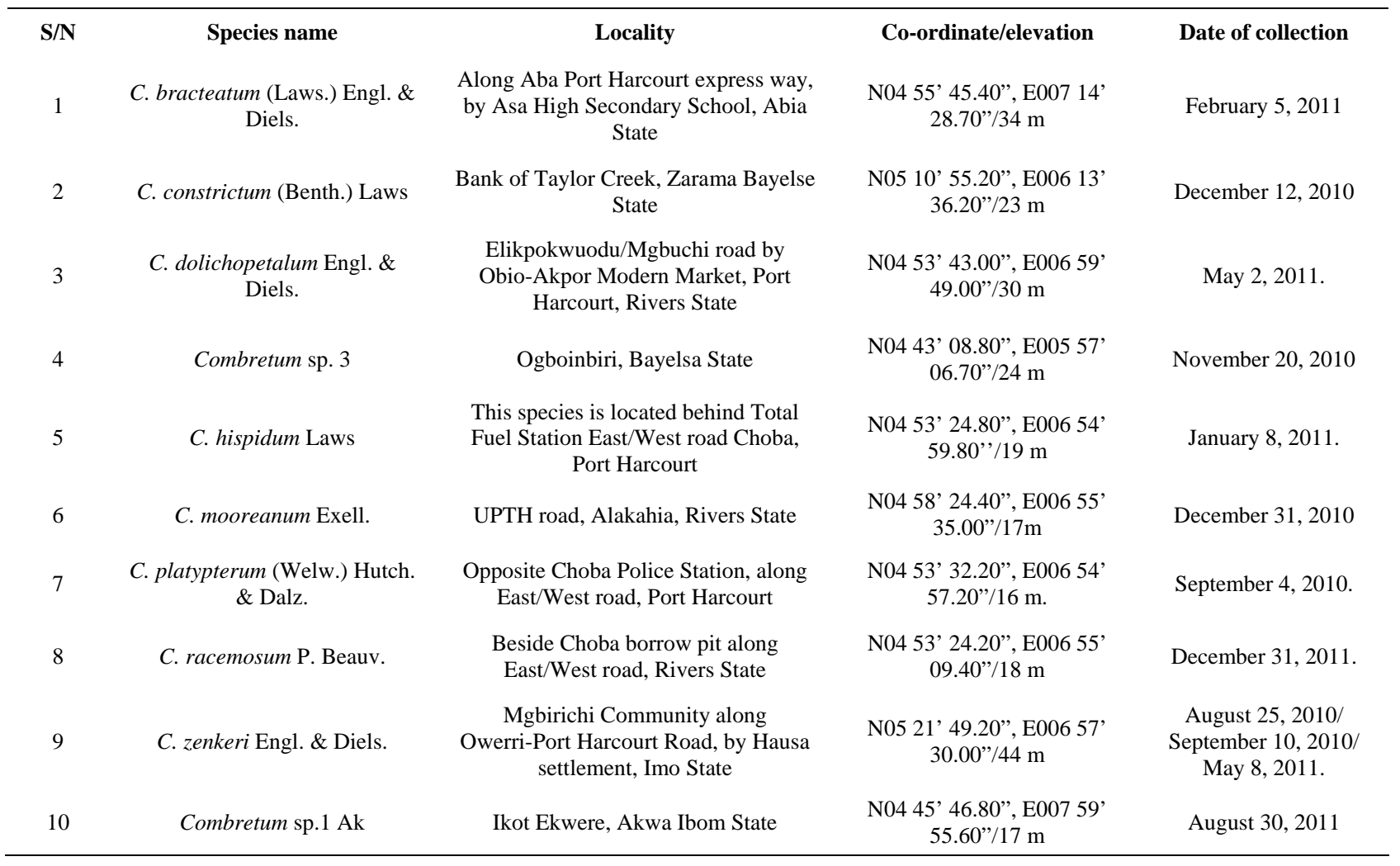

\section{Results}

The cytological observations on the taxa are presented in Table 2 and Figure 1(A)-(J). C. mooreanum, C. platypterum, C. bracteatum, C. hispidum, C. dolichopetalum and Combretum sp.2 have somatic chromosome number of $2 \mathrm{n}=26$. In C. racemosum and Combretum sp.3, a somatic chromosome number of $2 \mathrm{n}=39$ was recorded. However, variable somatic chromosome numbers of $2 \mathrm{n}=$ 26 and 39 were observed for $C$. zenkeri. These results suggest a basic number of $\mathrm{x}=13$ for the species studied.

The sizes of the chromosomes varied from species to species (Table 3). For instance, the smallest chromosome length was observed in Combretum sp.3 $(29.4 \pm 9.78 \mu \mathrm{m})$ while the longest were observed in C. mooreanum (84.65 \pm $17.13 \mu \mathrm{m})$. The lengths of chromosomes in the other species studied included C. hispidum $(40.38 \pm 6.73 \mu \mathrm{m})$, C. constrictum (39.42 $\pm 10.31 \mu \mathrm{m})$, C. bracteatum (44.91 \pm $12.58 \mu \mathrm{m})$, Combretum sp.2 (29.08 $\pm 8.86 \mu \mathrm{m})$, C. $r a-$ cemosum $(51.69 \pm 14.03 \mu \mathrm{m})$, C. zenkeri $(56.86 \pm 18.9$ $\mu \mathrm{m})$, C. platypterum $(41.35 \pm 8.40 \mu \mathrm{m})$ and C. dolichopetalum $(41.68 \pm 6.57 \mu \mathrm{m})$.

\section{Discussion}

Existing information on the chromosome numbers of this genus is scanty. Brighton and Wickens [12] reported a basic chromosome number of $\mathrm{x}=12$ or 13 in Combreta- ceae. In the genus Combretum, they reported basic numbers of $x=13$ and $2 n=26,39,52,78$ and 104 suggestive of diploid, triploid, tetraploid, hexaploid and octoploid levels. In this present study, ten species of the genus showed different cytotypes. C. mooreanum, C. platypterum, C. bracteatum, C. hispidum, C. dolichopetalum, C. consrtictum and Combretum sp.2 are diploids with chromosome numbers of $2 \mathrm{n}=2 \mathrm{x}=26$. However, $C$. racemosum and Combretum sp. 3 are triploid. Their somatic chromosome number is $2 \mathrm{n}=3 \mathrm{x}=39$. On the other hand, C. zenkeri is a mixoploid having chromosome number of $2 \mathrm{n}=2 \mathrm{x}=26$ (diploid) and $2 \mathrm{n}=3 \mathrm{x}=39$ (triploid) occurring in the somatic cell. This study confirms basic chromosome number of $\mathrm{x}=13$ for the Combretum species studied and is in agreement with earlier observations [12].

Polyploidy plays important role in the speciation of higher plants [11]. This occasionally manifests morphologically in variations such as flower colour, leaf and fruit sizes [14] with larger leaf sizes and reduced fertility (especially in triploids) being common with polyploids against their diploid counterparts [14,15]. Diploid members of Combretum studied were observed to have large broad leaves with showy inflorescences and large fruits as against the triploids, with reduced lance-shaped leaves. Inflorescences and fruits in the triploids were also reduced in size. Though these agree with earlier reports [14-16], further studies (field and experimental) are on- 


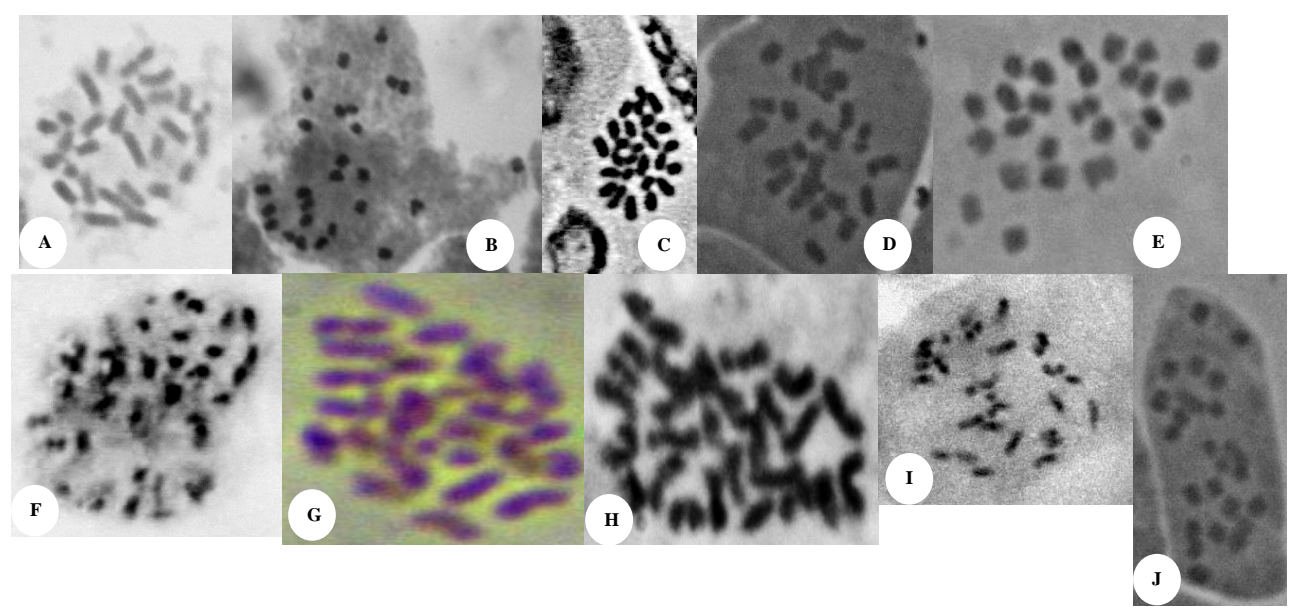

Figure 1. Chromosome configuration in the Combretum species studied. A. C. mooreanum $(2 \mathrm{n}=26)$; B. Combretum sp.2 $(2 \mathrm{n}=$ 26); C. C. platypterum ( $2 n=26)$; D. C. bracteatum $(2 n=26)$; E. C. hispidum $(2 n=26)$; F. Combretum sp.3 (2n = 39); G. C. zenkeri $(2 n=39) ;$ H. C. racemosum $(2 n=39)$; I. C. dolichopetalum $(2 n=26)$; and J. C. constrictum $(2 n=26)$.

Table 2. Chromosome numbers of species studied in the genus Combretum.

\begin{tabular}{ccc}
\hline S/N & Species name & Chromosome number \\
\hline 1 & C. platypterum & $2 \mathrm{n}=2 \mathrm{x}=26$ (diploid) \\
2 & C. racemosum & $2 \mathrm{n}=2 \mathrm{x}=39, \mathrm{x}=13$ (Triploid) \\
3 & Combretum $\mathrm{sp} .2$ & $2 \mathrm{n}=2 \mathrm{x}=26, \mathrm{x}=13$ (diploid) \\
4 & Combretum sp. 3 & $2 \mathrm{n}=2 \mathrm{x}=39, \mathrm{x}=13$ (Triploid) \\
5 & C. dolichopetalum & $2 \mathrm{n}=2 \mathrm{x}=26, \mathrm{x}=13$ (diploid) \\
6 & C. hispidum & $2 \mathrm{n}=2 \mathrm{x}=26, \mathrm{x}=13$ (diploid) \\
& C. zenkeri & $2 \mathrm{n}=2 \mathrm{x}=26, \mathrm{x}=13$ (diploid) \\
7 & $2 \mathrm{n}=3 \mathrm{x}=39, \mathrm{x}=13$ (Triploid) \\
8 & C. bracteatum & $2 \mathrm{n}=2 \mathrm{x}=26, \mathrm{x}=13$ (diploid) \\
9 & C. mooreanum & $2 \mathrm{n}=2 \mathrm{x}=26, \mathrm{x}=13$ (diploid) \\
10 & C. constrictum & $2 \mathrm{n}=2 \mathrm{x}=26, \mathrm{x}=13$ (diploid) \\
\hline
\end{tabular}

Table 3. Lengths of chromosomes in the Combretum species studied.

\begin{tabular}{cccc}
\hline Species name & $\begin{array}{c}\text { *Mean } \pm \text { STD } \\
(\boldsymbol{\mu m})\end{array}$ & Range $(\boldsymbol{\mu m})$ & $\begin{array}{c}\text { Coefficient of } \\
\text { variation }\end{array}$ \\
\hline C. hispidum & $40.38 \pm 6.73$ & $33.6-50.4$ & 16.67 \\
C. constrictum & $39.42 \pm 10.31$ & $21.0-63.0$ & 26.15 \\
C. bracteatum & $44.91 \pm 12.58$ & $21.0-63.0$ & 28.01 \\
Combretum sp.2 & $29.08 \pm 8.86$ & $16.8-42.0$ & 30.46 \\
C. mooreanum & $84.65 \pm 17.13$ & $105.0-42.0$ & 20.23 \\
C. racemosum & $51.69 \pm 14.03$ & $25.2-84.0$ & 27.13 \\
C. zenkeri & $56.86 \pm 18.90$ & $33.6-84.0$ & 33.23 \\
C. dolichopetalum & $41.68 \pm 6.57$ & $33.6-54.6$ & 15.76 \\
C. platypterum & $41.35 \pm 8.40$ & $25.2-54.6$ & 20.31 \\
Combretum sp.3 & $29.40 \pm 9.78$ & $16.8-42.0$ & 33.27 \\
\hline
\end{tabular}

"Measurements based on 16 cells. going for detailed morphological and reproductive comparison of features between the diploids and polyploids in the genus.

\section{REFERENCES}

[1] L. S. Gill, “Taxonomy of Flowering Plants,” AfricanaFep Publishers Ltd., Onitsha, 1988.

[2] J. Hutchinson and J. M. Dalziel, "Flora of West Tropical Africa,” Crown Agents for Oversea Governments and Administrations, London, 1958.

[3] R. W. J. Keay, “Trees of Nigeria,” Oxford University Press, New York, 1989.

[4] L. Watson and M. J. Dallwitz, "Combretum bracteosum Extracts as Eco-Friendly Corrosion Inhibitor for Mild Steel Acidic Medium,” Pigment Technology, Vol. 38, No. 4, 2009, pp. 236-241. doi:10.1108/03699420910973323

[5] D. M. W. Anderson, J. R. A. Millar and W. Weiping, "The Gum Exudate from Combretum nigricans Gum, the Major Source of West African 'Gum Combretum',' Food Additives and Contaminants, Vol. 8, No. 4, 1991, pp. 423436. doi:10.1080/02652039109373992

[6] D. M. W. Anderson, "Water Soluble Plant Gum Exudates. 2. The 'Combretum' Gums,” Process Biochemistry, Vol. 13, No. 7, 1978, pp. 4-5.

[7] L. J. McGaw, T. Rabe, S. G. Sparg, A. K. Jager, J. N. Eloff and J. van Staden, "An Investigation on the Biological Activity of Combretum Species,” Journal Ethnopharmacology, Vol. 75, No. 1, 2001, pp. 45-50. doi:10.1016/S0378-8741(00)00405-0

[8] A. Salvat, L. Antonnacci, R. H. Fortunato, E. Y. Suarez and H. M. Godoy, "Screening of Some Plants from Northern Argentina for Their Antimicrobial Activity,” Letters in Applied Microbiology, Vol. 32, No. 5, 2001, pp. 293297. doi:10.1046/j.1472-765X.2001.00923.X

[9] M. E. Arias, J. D. Gomez, N. Cudmani, M. A. Vattuone and M. I. Isla, "Antibacterial Activity of Ethanolic and Aqueous Extract of Acacia aroma Gill ex Hook et Arn,” 
Life Science, Vol. 75, No. 2, 2004, pp. 191-202. doi:10.1016/j.lfs.2003.12.007

[10] D. Karou, H. M. J. Dicko and A. S. Traore, “Antioxidant and Antibacterial Activities of Polyphenols from Ethnomedicinal Plants of Burkina Faso," African Journal of Biotechnology, Vol. 4, No. 8, 2005, pp. 823-828.

[11] C. A. Stace, "Plant Taxonomy and Biosystematics," Edward Amold Publishers Ltd., London, 1980.

[12] C. A. Brighton and G. E. Wickens, "Some Chromosome Counts in the Genus Combretum (Combretaceae)," Kew Bulletin, Vol. 31, No. 1, 1976, pp. 5-8. doi:10.2307/4108991

[13] B. C. Ndukwu and B. E. Okoli, “Cytological Techniques,”
In: B. E. Okoli, Ed., Field, Herbarium and Laboratory Techniques, Mbeyi and Associates Nigeria Ltd., Lagos, 1992, pp. 65-72.

[14] C. U. Agbo and N. U. Ukwu, "Morphology and Chromosome Numbers of Gongronema latifolia Benth. Clones from Nigeria," African Crop Science Journal, Vol. 19, No. 1, pp. 29-38.

[15] G. L. Stebbins, "Types of Polyploids, Their Classification and Significance,” Advances in Genetics, Vol. 1, 1949, pp. 403-409. doi:10.1016/S0065-2660(08)60490-3

[16] R. .W. Allard, "Principles of Plant Breeding,” John Wiley and Sons Inc., New York, 1980. 